\title{
The Prediction Power of Servant and Ethical Leadership Behaviours of Administrators on Teachers' Job Satisfaction
}

\author{
Semra Kıranlı Güngör \\ Faculty of Education, Eskisehir Osmangazi University, Turkey
}

Copyright $(2016$ by authors, all rights reserved. Authors agree that this article remains permanently open access under the terms of the Creative Commons Attribution License 4.0 International License

\begin{abstract}
The purpose of this study is to identify servant leadership and ethical leadership behaviors of administrators and the prediction power of these behaviors on teachers' job satisfaction according to the views of schoolteachers. This research, figured in accordance with the quantitative research processes. The target population of the research has consisted of 319 schoolteachers working in the city center of Eskişehir in 2016--2017 academic year. They are selected randomly in Eskişehir province to identify the participants of the survey, participated in the study voluntarily. In this study as a descriptive research, mean score, standard deviation values, Pearson's product-moment correlation and multiple regression analysis was utilized for analysis of the data. According to correlation analyses, servant leadership is in negative direction with ethical leadership and job satisfaction. There is a negative relation between all dimensions of servant leadership and job satisfaction. Ethical leadership is in positive relation with job satisfaction. Ethical leadership is in positive relation with all dimensions of job satisfaction. According to the results of regression analyses, job satisfaction increases when ethical leadership increases, job satisfaction decreases when servant leadership increases.
\end{abstract}

Keywords Ethical Leadership, Servant Leadership, Job Satisfaction, Educational Administration, Quantitative Research

\section{Introduction}

According to M.E.B, (1) centralist administration exists in Turkey. Ministry of National Education in the area of Ministries in Ankara, is the center. All of 81 provinces in Turkey with Ankara, the center of Ankara, except the building of Ankara Ministry of Education, are called provincial organization. $4+4+4$ system of education has been accepted since 2012-2013 academic year and 12 years education has been obligatory. Elementary school consists of
4 years primary school period, 4 years secondary school period. Afterwards, there is high-school education period that consists of 4 years high school training. This training includes elementary and high school education period. Then continuation of education is optional and the ones who desire can continue their education by getting enough score from the test examination for their desired department which is university exam performed with the central system. Education is underway in state schools and private schools depending on the state.

According to M.E.B (1) General High-School Education includes all of the general education institutions depending on elementary school education, which supply minimum 4 years education. According to the 26th article of National Education basic law, high-school education includes all of the general, professional, and technical education institutions depending on elementary school education, which supply minimum 4 years education. The academic period of 3 years general, professional, and technical high schools has been increased to 4 years fractionally from the 9th grade since 2005-2006 academic year. High school education has been 4 years.

Schools are communities, which include staffs, teachers, students and school administrators. School administrators must think apply different leadership for their staffs' job satisfaction. School administrators lead their school, which they work using ethical leadership and servant leadership related to ethics.

Ana Marie Villegas \& et al. explain that (2) school administrators should adopt ethical management in schools to solve some problems and changing inequities According to James Owens, (3) there are many definitions of ethics. The Ethics is derived from a Greek word ethos. Ethics is a set of standards or codes that includes the definition of human activities that can be defined mistakes, good and bad. Pat Mahony (4) signs ethics and morals have different meanings, as they are related and close to each other, they are both used in the same meaning. Annemarie Pieper (5) expressed that ethics is the code of values and moral principles that guides 
individual or group behavior with respect to what is right or wrong. Ethics is the study of moral acts and judgments. Pat Mahony (4) states differences between ethics and moral. While morals are interested in application of the rules, ethics is a branch of philosophy, which is interested in cause of the rules. Ethics is interested in right and wrong, should and should not, good and bad.

Leadership is a relation between a leader and his followers in an organizational context. Ethical leadership is an important in providing direction for the organization's success and reach specified goals are expressed by Rabindra N. Kanungo, \& et al (6). Ethical leadership is depending on ethical rules, principles, values, belief and they lead his organization using them (Robert Starratt) (7). Ethical leaders are good role models. They are honest and principled leaders who do the right thing and scrape along their personal lives in an ethical manner. They are honest, fair and make ethical decisions. They have good communication and they listen others. They use clear ethical standards in their organization to lead. They are supportive and caring leaders that listen to, and are trusted by, their subordinates. Ethical leaders think their responsibility and their staff and community's in every attitude and behavior. (Michael E. Brown \& et al.) (8).

According to Robert Greenleaf, (9) a servant leader is also an ethical leader. "The Servant as Leader" defined servant leadership. The effective leader acts as a servant to staffs that empower others to reach success by doing things on right action. The ethical leader understands the truth of people mutual attachment to each other, and that it is through their intentness to serve each other. Thus, people use their whole potential, energy and power to get the greater for whole organization. According to Sen Sendjaya \& et al, (10) describes servant leadership who has holistic thinking, employee oriented, dependent on moral values, stewardship.

According to Dirk van Dierendonck, (11) it is argued that servant leadership is displayed by leaders who combine their motivation to lead with a need to serve. Personal characteristics and culture are positioned alongside the motivational dimension. Servant leadership is demonstrated by empowering and developing people; by expressing humility, authenticity, interpersonal acceptance, and stewardship; and by providing direction. A high-quality dyadic relationship, trust, and fairness are expected to be the most important mediating processes to encourage self-actualization, positive job attitudes, performance, and a stronger organizational focus on sustainability and CSR.

Thomas Sergiovanni (12) states that servant leadership should be powerful. When people are served, their response is affected by their emotions and connections. Muel Kaptein (13) states that ethical leader's effectiveness is required authenticity, which is a precondition for integrity. Robert Starratt (7) tells that authentic leaders apply authenticity in their relationships with their staff, students, parents and others. They make real their authentic relations every day. Gary Yukl (14) defines that authenticity is also sub-dimension under servant leadership. Authenticity includes moral perspective and self-awareness. Bruce J. Avolio \& et al (15) defines authentic leaders. Authentic leaders are individuals who have a deep awareness of their own, others' values/perspectives, and the context in which they manage. They have positive point of view to people and job. Gary Yukl (14) informs about integrity. Integrity is a behavior of servant leaders, which includes honesty, trustworthy, and values.

School administrators' ethical leadership has a great effect on job satisfaction of teachers. There are many definitions about job satisfaction. Edwin A. Locke (16) describes job satisfaction as nice and positive feelings of a person occurred, because of evaluation of his/her own job and job experience. Alex C. Michalos (17) signs that job satisfaction is an emotional situation and a cognitive judgement related to effect of employees' administration and leadership practice at work. James J. Cribbin (18) thinks that job satisfaction is in proportion to administrators' valuing his/her employees, caring them, encouraging them, improving job conditions for them, developing good relationships among employees and between employee and the administrator mutually, providing positive communication, that is, being able to perform ethical leadership. Ali Balc1 (19) Factors such as job and its quality, pay, organization, environment, promotion chance, on which level one's value and expectations are answered and on which level the employee understands this answering condition is important. That means the relation between these two conditions is the determinant of the employee's condition of satisfaction or dissatisfaction.

\subsection{Aims}

It is important to identify servant leadership and ethical leadership behaviors of administrators and the prediction power of these behaviors on teachers' job satisfaction according to the views of schoolteachers.

The research question aims to find out the effects of servant and ethical leadership behaviors of principals on teachers' job satisfaction.

Our sub-questions are:

1. Which level are the principals' perceptions of servant and ethical leadership and teachers' job satisfaction?

2. Is there a relation between the principals' perceptions of servant and ethical leadership and teachers' job satisfaction?

3. How is the prediction power of servant and ethical leadership behaviors of principals on teachers' job satisfaction?

\section{Materials and Methods}

\subsection{The Research Method}

This research is relational research. Jack R. Fraenkel \& et 
al (20) indicates that the basic examples of relational research are correlation and causal comparative research studies. James H. McMillan \& et al (21) tells that correlational design evaluates the relations between two or more cases. John W. Creswell (22) defines correlation research. In correlation research, researchers find out the relation between two or more variables by using correlation statistics without having the variables under their control and manipulating them. This research follows the quantitative research processes. The study, which has been conducted in order to examine the prediction power of servant and ethical leadership behaviors of principals on teachers' job satisfaction by using correlational design (correlational model).

\subsection{Target Population of the Research and Participants}

High school teachers, who are selected randomly in Eskişehir city center in Turkey province for the purpose of identifying the participants of the survey, participated in the study voluntarily.319 teachers participated in the study.109 teachers is male and 210 teachers is female. Of the participants, 34.2 percent of is male and 65.8 percent is female. Their ages are at different ranges. As seniority, there is 48, 9 percent with 156 people between $1-10,26,6$ percent with 85 people between $11-20,20,1$ percent with 64 people between $21-30,4,4$ percent with 14 people between 41-45.Information about the demographic features of the participants is presented in Table 1.

Table 1. Range of the Participants' Demographic Information

\begin{tabular}{|c|c|c|c|c|c|c|c|}
\hline \multicolumn{2}{|c|}{ Options } & 1 & 2 & 3 & 4 & 5 & Total \\
\hline \multirow{4}{*}{ Sex } & & Men & Women & & & & - \\
\cline { 2 - 8 } & $n$ & 109 & 210 & & & & 319 \\
\cline { 2 - 9 } & $\%$ & 34.2 & 65.8 & & & & 100 \\
\hline \multirow{4}{*}{ Age } & & $25-30$ & $31-35$ & $36-40$ & $41-45$ & +46 & - \\
\cline { 2 - 9 } & $n$ & 34 & 65 & 79 & 46 & 95 & 319 \\
\cline { 2 - 9 } & $\%$ & 10.7 & 20.4 & 24.8 & 14.4 & 29.8 & 100 \\
\hline \multirow{4}{*}{ Seniority } & $n$ & $1-10$ & $11-20$ & $21-30$ & +31 & & - \\
\cline { 2 - 8 } & $\%$ & 48.9 & 26.6 & 20.1 & 4.4 & & 100 \\
\cline { 2 - 8 } & & 156 & 85 & 64 & 14 & & 319 \\
\hline
\end{tabular}

\subsection{Data Collection Tool}

In this study, Servant Leadership Scale, Ethical leadership scale and Job satisfaction scale have been used as data collection tools. Features of these tools are explained below.

\subsection{Analysis and Interpretation of the Data, Validity and Reliability}

\section{Servant Leadership Scale}

The scale was developed by Dirk Van Dierendonck \& et al (23). Scale, which is composed of eight factors including empowerment, standing back, accountability, forgiveness, courage, authenticity, humility, stewardship was adapted in Turkish culture by Emin Cihan Duyan \& et al.(24) at first time. Confirmatory factor analysis was conducted in order to determine the construct validity of the scale in this study. In this context, whether the estimated values rise to theoretical limits or not was determined before conducting the confirmatory factor analysis for scale factors. According to the obtained result, it was found that values were not rising to theoretical limits. In confirmatory factor analysis, fit index values, Chi-Square value $\left(\chi^{2}\right)$ and significance levels are calculated as $\left[\chi^{2}=123,41, d f=74\right]$. Other goodness of fit index values of the models $[G F I=0.94, A G F I=0.96, C F I=0.91$, $R M S E A=0.07]$ demonstrated that proposed model is appropriate. Item loadings, which are obtained from confirmatory factor analysis, ranged from 0.37 to 0.81 . Cronbach alpha internal consistency coefficients were ranked between 0.75 and 0.87 for factors and it was calculated as 0.89 for the whole scale. As a result, Servant Leadership Scale has a six point likert, which consists of 30 items and seven factors described as empowerment, standing back, accountability, forgiveness, courage, authenticity, humility, stewardship.

\section{Ethical Leadership Scale}

Scale was developed by Michael. E. Brown \& et al. (25) Composed of a single factor, was adapted in Turkish culture by Tuna \& et al. (26) Confirmatory factor analysis was conducted in order to determine the construct validity of the scale in this study. In this context, whether the estimated values rise to theoretical limits or not was determined before conducting the confirmatory factor analysis for scale factors. According to the obtained result, it was found that values were not rising to theoretical limits. In confirmatory factor analysis, fit index values, Chi-Square value $\left(\chi^{2}\right)$ and significance levels are calculated as $\left[\chi^{2}=67.12, d f=32\right]$. Other goodness of fit index values of the models $[G F I=0.96$, $A G F I=0.96, C F I=0.93, R M S E A=0.04]$ demonstrated that proposed model is appropriate. Item loadings, which are obtained from confirmatory factor analysis, ranged from 0.41 to 0.88 . Cronbach alpha internal consistency coefficient was calculated as 0.79.As a result, Ethical Leadership Scale has a five-point likert, 10 items and a single factor.

\section{Job Satisfaction Scale}

Scale was developed by Paul Elliot Spector (27). Scale, which is composed of nine factors including pay, promotion, supervision, fringe benefits, contingent rewards, operating conditions, co-workers, nature of work, communication, was adapted in Turkish culture by Şişman \& et al.(28). Confirmatory factor analysis was conducted in order to determine the construct validity of the scale in this study. In this context, whether the estimated values rise to theoretical limits or not was determined before conducting the confirmatory factor analysis for scale factors. According to the obtained result, it was found that values were not rising to theoretical limits. In confirmatory factor analysis, fit index values, Chi-Square value $\left(\chi^{2}\right)$ and significance levels are 
calculated as $\left[\chi^{2}=217,41, d f=91\right]$. Other goodness of fit index values of the models $[G F I=0.90, A G F I=0.91, C F I=0.89$, $R M S E A=0.08]$ demonstrated that proposed model is appropriate. Item loadings, which are obtained from confirmatory factor analysis, ranged from 0.32 to 0.82 . Cronbach alpha internal consistency coefficients were ranked between 0.71 and 0.79 for factors and it was calculated 0.82 for the whole scale. As a result, Job Satisfaction Scale has a five-point likert, 35 items and nine factors described as pay, promotion, supervision, fringe benefits, contingent rewards operating conditions, co-workers, nature of work, communication.

Data Analysis (treatment)

Data were obtained through conducting data collection tools to high school teachers by the researcher in the survey. Demographic variables were grouped before statistical analysis and then scales, which were conducted to working group, were graded. Frequency (n) and percent values (percentage) that determine the demographical features of personnel composing the research group were found. Afterwards, mean $(X)$ and standard deviation $(S S)$ scores were calculated for the scores obtained from the scales. In the analyses related to sub purposes of the study;

Barbara G. Tabachnick (29) thinks to determine whether there is a significant relation between perceptions of principals' servant leadership, ethical leadership and teachers' job satisfaction, The Pearson product moment correlation analysis, In order to determine the prediction level of servant and ethical leadership behaviors of principals on teachers' job satisfaction, multiple regression analysis was used. Whether variables have affected each other and what the explanation strength has been exposed by multiple regression analysis.

\section{Findings}

\section{Results Related to Descriptive Statistics}

Descriptive statistics related to high school teachers' perceptions of principals' servant and ethical leadership and job satisfaction of high school teachers are presented in Table 2.

As it is seen in table, mean score of high school teachers' perceptions of principals' ethical leadership is at low-level with 2.26 .

When teachers' perceptions of servant leadership are examined, the highest mean score is on the factor of "accountability" with 4,24 the lowest mean score is on the factor of "forgiveness" with 3,78 and the total mean score is 4,03. According to this, it can be said servant leadership of high school teachers is at high level.
When job satisfaction scores of high school teachers are examined, the highest mean score is on the factor of "pay" with 3,82 the lowest mean score is on the factor of "operating conditions" with 3,26 and the total mean score is 2.86. According to this, it can be said job satisfaction of high school teachers is at middle and mid-lower level.

Table 2. Mean Score and Standard Deviation Values Related To High School Teachers' Perceptions of Principals' Servant and Ethical Leadership and Job Satisfaction of High School Teachers

\begin{tabular}{|c|c|c|c|}
\hline Scales & $\mathrm{N}$ & $\mathrm{X}$ & SS \\
\hline Ethical leadership & 319 & 2.26 & .77 \\
\hline \multicolumn{4}{|l|}{ —Servant Leadership factors } \\
\hline 1- Empowerment & 319 & 4.17 & 1.06 \\
\hline 2-Standing back & 319 & 4.01 & 1.12 \\
\hline 3-Accountability & 319 & 4.24 & 1.03 \\
\hline 4-Forgiveness & 319 & 3.78 & 0.72 \\
\hline 5-Courage & $316^{*}$ & 3.81 & 0.86 \\
\hline 6-Authenticity & 319 & 3.78 & 0.78 \\
\hline 7-Humility & 319 & 3.99 & 0.95 \\
\hline 8-Stewardship & 319 & 4.22 & 1.11 \\
\hline Servant leadership total mean score & 319 & 4.03 & 0.73 \\
\hline \multicolumn{4}{|l|}{ Job satisfaction factors } \\
\hline 1- Pay & 319 & 3.82 & .73 \\
\hline 2-Promotion & 319 & 3.06 & .61 \\
\hline 3-Supervision & 319 & 2.55 & .80 \\
\hline 4-Fringe benefits & 319 & 3.03 & .71 \\
\hline 5-Contingent rewards- & 319 & 2.99 & .78 \\
\hline 6-Operating conditions & 319 & 3.26 & .55 \\
\hline 7-Co-workers & 319 & 2.31 & .80 \\
\hline 8-Nature of work & 319 & 2.26 & .80 \\
\hline 9- Communication. & 319 & 2.50 & .66 \\
\hline Job satisfaction total mean score & 319 & 2.86 & .44 \\
\hline
\end{tabular}

* (only 3 people did not give answers that questions related that courage)

Results Related to Relations between Servant Leadership, Ethical Leadership and Job Satisfaction

In Table 3, results of Pearson product moment correlation analysis, which was conducted for the evaluation of relation between high school teachers' perception of servant and ethical leadership and their job satisfaction, were demonstrated. Principals' servant leadership behaviors of high school teachers was found significant statistically in negative direction with both ethical leadership $(\mathrm{r}=-.45)$ and their job satisfaction ( $\mathrm{r}=-$.44.) On the other hand, a relation significant statistically in positive direction $(\mathrm{r}=.44)$ was found between ethical leadership and their job satisfaction. There is a correlation between ethical leadership and job satisfaction. Statistically significant in negative directed relations were found among all factors of servant leadership and job satisfaction. In addition, relations statistically significant in positive directed relations were found among all factors of ethical leadership and job satisfaction. 


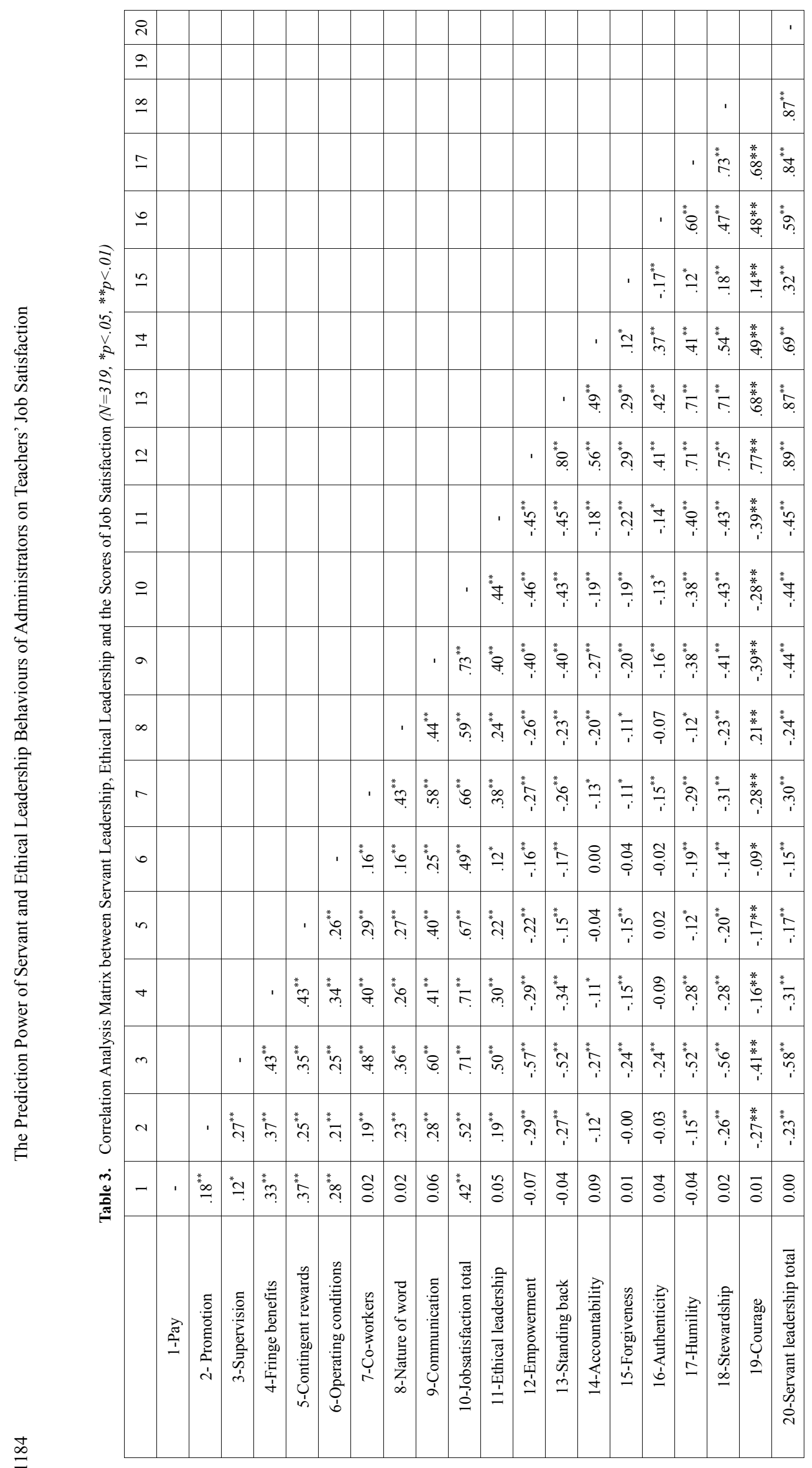


Results Related to the Prediction Power of Servant and Ethical Leadership Perceptions on Teachers' Job Satisfaction

In Table 4, results of multiple regression analysis, which was conducted for predicting high school teachers' job satisfaction by the perception of their principals' servant and ethical leadership, were demonstrated.

When results of multiple regression analysis related to prediction of principals' servant and ethical leadership perceptions of high school teachers on teachers' job satisfaction are examined, the prediction power of servant and ethical leadership scores on teachers' job satisfaction are found significant statistically $\left[\mathrm{F}_{(2,319)}=59.64, p<.01\right]$.

In the study, it is determined that servant and ethical leadership can explain 27 percent of the change $[R=.52$, $\mathrm{R} 2=.27]$ in the job satisfaction. Furthermore, when the results of T-test related to meaningfulness of regression coefficients are examined. It is determined that servant leadership is a significant predictive on job satisfaction and servant leadership negatively. If ethical leadership increases one unit, job satisfaction increases 0,308 . On the other hand, it is determined that ethical leadership is a significant predictive on job satisfaction positively. If servant leadership increases one unit, job satisfaction decreases 0,307 . It is determined that ethical leadership is a significant predictive on job satisfaction negatively.

Table 4. Multiple Regression Analysis Matrix Related to Prediction of Job Satisfaction

\begin{tabular}{|c|c|c|c|c|c|}
\hline Variations & $B$ & $S H_{B}$ & $\beta$ & $t$ & $p$ \\
\hline Fixed & 3.217 & .177 & & 18.209 & .000 \\
\hline 1-Ehical leadership & .178 & .031 & .308 & 5.725 & .000 \\
\hline 2-Stewardshipleadership & -.186 & .033 & -.307 & -5.705 & .000 \\
\hline \multicolumn{6}{|c|}{$N=319 ; R=.52 ; R^{2}=.27 ; F=59.64 ; p<.01$} \\
\hline
\end{tabular}

\section{Discussions and Conclusions}

The purpose of this study has been to identify servant leadership and ethical leadership behaviors of administrators and the prediction power of these behaviors on teachers' job satisfaction according to the views of schoolteachers. This research, figured in accordance with the quantitative research processes. Therefore servant leadership scale, ethical leadership scale, job satisfaction scale has been used for research.

In brief, the results of the research show that ethical leadership and job satisfaction exist concurrently. There is not a positive relation between all dimensions of servant leadership and job satisfaction. If ethical leadership exists, there is a positive relation with all dimensions of job satisfaction. If servant leadership exists, ethical leadership does not exist. If servant leadership exists, job satisfaction does not exist.

In this study, research result related with ethical leadership is similar to the finding in many researches in literature. It's result similar to Emine Çengelci (30), Halil Ertürk (31),
Çetin Erdoğan (32) Celal Tayyar Uğurlu (33) Birsel Aktoy (34), İbrahim Baştuğ (35) and Ahu Taneri (36)'s research result. Their results show that administrators of primary schools perform high level of ethical leadership behaviors according to teacher's view. The teachers perceived that the behaviors of schools principals are related with ethical principles and that the organizational health of the schools is high. There is a positive relationship on an intermediate level between the ethical leadership behavior and the organizational health. This research finding is different from the finding Muhammed Turhan (37)'s research result. His research result indicate that teachers do not find them entirely successful in solving the ethical dilemmas and deciding ethically and in the trust based leadership when the principals find themselves as successful in the roles of ethical leadership.

This research result related with ethical leadership and job satisfaction is similar to the finding Sedat Çelik \& et al. (38), Alptekin Sökmen's (39), Canan Madenoğlu \& et al's (40) research result. Their result shows that ethical leadership has a positive effect on employees' job satisfaction. When ethical leadership behaviors increase, job satisfaction increases. Münevver Çetin \& et al. (41) research result shows ethical leadership has an effect on employees' job satisfaction, but there is no strong relation and effect.

This research result related with servant leadership is different from the finding, which is listed in rows. Mikail Yalçın \& et al.'s (42) research result. It shows that there were significant relationships between servant leadership and school culture but servant leadership did not have direct effects on school culture. Refik Balay \& et all's (43) research results shows that managers can use of servant leadership competences to use differences effectively for the goals of the organization. It shows that the study revealed that managers are found to have a medium level of servant leadership competences and management of differences skills. Hakk1 Kahveci \& et al.'s (44) research result show that a significant positive and high relationship between the servant leadership and school culture. Servant leadership is the predictor of school culture.

In this study, there is no positive relation between ethical leadership and servant leadership. Additionally, there is no positive relation between job satisfaction and servant leadership. It is different result from the literature. Perhaps Turkish people want authority; they find servant leadership a weak leadership. They know something about ethical leadership because morality is important for them as a tradition, though, in Lora L. Leed \& et al., (45) servant leadership can be seen as one form of ethical leadership because value and moral are common in both of them.

Gary Yukl (14) states that leadership behavior is influenced by culture. The values and culture can be change over time. Cultural values show leaders' behavior and beliefs. Power distance is one of the value dimensions. On the other hand, Turkish leaders give importance power much. They want to have power much than everything. Ümit Ercan \& et al. (46) stated leadership is a field of study, which is 
considerably affected by the cultural differences. There are differences between Turkish and other countries' leaders regarding cultural values, and the effects of these differences on their leadership behaviour. Cem Harun Meydan and et al. (47) study result and Gary Yukl (14)'s statement have similar about power distance. Power distance involves the acceptance of an unequal distribution of power and status in organizations and institutions. In high power distance cultures, people expect the leaders to have greater authority with rules and directives. They obey the rules without questioning or challenging them. They have no struggle or no brave decisions against the authority. Lora L. Leed \& et al. (45) tell about the discussion in the social nature of leadership. Authority involves the legitimated rights of a position that require others to obey. Leadership is an interpersonal relation in which others comply because they want to, not because they have to.

There is a one point if cultural leadership scale, as a fourth scale was used in this study we could talk about the effects on ethical, servant leadership a job satisfaction. Consequently, it can be tried in any new research. Maybe original scales can be developed for Turkish culture, so adopted scale effect can be extinctive from the beginning of the research. In different groups, research can produce different result.

\section{REFERENCES}

[1] M.E.B. (Ministry of National Education) Millî Eğitim Bakanlığı Ortaöğretim Kurumları Yönetmeliği. (Ministry of National Education, regulations on secondary education institutions). Online available from http://mevzuat.meb.gov.t r/html/ortaogrkurumyon_0/ yonetmelik.pdf

[2] Ana Marie Villegas and Tamara Lucas, T. The culturally responsive teacher. Educational Leadership, Vol. 64. Issue: 6, 28-33, 2007.

[3] James Owens. Ethical Theory and Business Decisions. The American University, Management Education Maryland Publication, U.S.A. 1978.

[4] Pat Mahony, Should 'ought' be taught? Teaching and Teacher Education, Vol. 25. Issue 7, 983-989, 2009

[5] Annemarie Pieper Einführung in die Ethik (Sechste überarbeitete und aktualisierte Auflage) A Francke Verlag Publication, Germany, 2007.

[6] Rabindra N.Kanungo, \& Manuel Mendonca. Ethical dimensions of leadership: Sage Publications, London, 1996.

[7] Robert Starratt. Ethical leadership. (First edition). Jossey-Bass, England, 2004.

[8] Michael E. Brown, and Linda. Kilebe. Treviño. Ethical Leadership: A Review and Future Directions The Leadership Quarterly, Vol. 17. Issue.6: 595-616, 2006 DOI:10.1016/j.le aqua.2006.10.004

[9] Robert Greenleaf, Servant Leadership — A Journey into the
Nature of Legitimate Power and Greatness Paulist Pres, U.S.A. 1977

[10] Sen Sendjaya, and Brian Cooper. Servant leadership behaviour scale: a hierarchical model and test of construct validity. European Journal of Work and Organizational Psychology, Vol: 20, Issue:3, 416-436. 2011.

[11] Dirk van Dierendonck. Servant Leadership: A Review and Synthesis. Journal of Management. Vol: 37 Number: 4, 1228-1261, 2011 DOI: 10.1177/0149206 310380462

[12] Thomas, J. Sergiovanni. Moral Leadership: Getting to the hearth of school improvement. John Wiley \& Sons Inc. U.S.A.,1992.

[13] Muel Kaptein. The diamond of managerial integrity. European Management Review. Vol. 21 Issue.1. 99- 108, 2003.

[14] Gary Yukl, Leadership in organizations, (5th edition). Upper Saddle River, NJ: Prentice Hall, U.S.A., 2002.

[15] Bruce J. Avolio, and William L. Gardner, W. L. 'Authentic leadership development: getting to the root of positive forms of leadership'. Leadership Quarterly, 16, 315-38, 2005 DOI: 10.1016/j.leaqua.2005.03.001

[16] Edwin A. Locke. Nature and Causes of Job Satisfaction. Handbook of Industrial and Organizational Psychology (Editor: J. Durnette). Wiley and Sons, U.S.A., 1983

[17] Alex C. Michalos. Multiple discrepancies theory (MDT). Social Indicators Research, Vol: 16, 347-413., 1985. DOI: 10.1007/BF0333288.

[18] James J. Cribbin Effective managerial leadership. American Management Association, New York 1972.

[19] Ali Balc1. Eğitim Yöneticisinin İş Doyumu. (Job satisfaction of educational administator) Yayımlanmamış doktora tezi. (Unpublished doctorate thesis) Ankara University, Institute of Social Sciences, Ankara, 1985.

[20] Jack R. Fraenkel, Norman E. Wallen and Helen Hyun. How to design and evaluate research in education. McGraw-Hill, New York, 2012.

[21] James H. McMillan, Sally Schumacher Research in Education: Evidence-Based Inquiry. Education Research in Education (Seventh edition) Pearson, U.K., 2004

[22] John W. Creswell. Educational research planning, conducting and evaluating quantitative and qualitative research (2nd ed.). Education. Pearson, New Jersey, 2005.

[23] Dirk. Van Dierendonck, and Nuijten, I.A.P.M. The Servant Leadership Survey: Development and validition of a multidimensional Measure. Journal of Business and Psychology, Vol: 26 Issue 3, 249-267, 2011. DOI: http://dx.doi.org/10.1007/s10869-010-9194-1

[24] Emin Cihan Duyan and Dirk van Dierendonck. Understandıng Servant Leadershıp: From Theory To Empirical ResearchSosyoloji Konferansları Dergisi, (İstanbul Journal of Sociological Studies) Vol: 49. Issue.1. 1-32, 2014

[25] Michael. E., Brown,; Linda. K Treviño, and David. A. Harrison. A Social Learning Perspective For Construct Development And Testing. Ethical Leadership Organizational Behavior and Human Decision Processes. Vol. 97, Issue 2, 117-134, 2005. 
[26] Muharrem Tuna - Hüdaverdi Bircan and Murat Yeşiltaş. Reliability and Validity of Ethical Leadership Scale: Case of Antalya. Atatürk University, Journal of economics and administrative sciences. Vol:26, Issue: 2, 143-145. 2012

[27] Paul Elliot Sepector. Assessing employee job satisfaction with the job satisfaction survey. Mental Retardation Systems, Vol: 3, 5-13, 1986.

[28] Mehmet Şişman and Selahattin Turan Bazı Örgütsel Değişkenler Açısından Calıșanların İs Doyumu Ve Sosyal Duygusal Yalnızlık Düzeyleri (Meb Şube Müdür Adayları Üzerinde Bir Araştırma)- (A Study Of Correlation Between Job Satisfaction And Social-Emotional Loneness of Educational Administrators in Turkish Public Schools). Osmangazi University, Journal of Social Sciences. Vol: 5 Issue: $1,117-128,2004$

[29] Barbara G. Tabachnick, and Linda S Fidel. (Fourth edition) Using Multivariate Statistics. Pearson Education Company, USA, 2001

[30] Emine Çengelci. Okul Yöneticilerinin Etik Liderlik Davranışları (Ethical Leadership Behaviours of School Principals) Yayınlanmamış Yüksek Lisans Tezi (Unpublished Master Thesis), Afyon Kocatepe University, The Institute Of Social Sciences, Afyon, 2014.

[31] Halil Ertürk. Okul Müdürlerinin Etik Liderlik Davranış Düzeylerinin İncelenmesi (Uşak İli Örneği) [A Research On The Ethical Leadership Level of School Principals (Usak City Sample)] Yayınlanmamış Yüksek Lisans Tezi (Unpublished Master Thesis), Uşak University, The Institute of Social Sciences, 2012

[32] Çetin Erdoğan. İlköğretim okulu müdürlerinin davranışlarının etik ilkelere uygunluğu. (Accordance of Elementary School Principals' Behaviors with the Code of Ethics) Kastamonu Eğitim Dergisi (Kastamonu Education Journal) Vol: 20. Issue: 2, 503-518, 2012.

[33] Celal Tayyar Uğurlu. İlköğretim Okulu Öğretmenlerinin Yönetici Etik Liderlik Davranışına İlişkin Algıları (The Perceptions of Primary School Teachers Regarding Administratior Ethic Leadership Behavior). Cumhuriyet University, Sosyal Bilimler Dergisi (Journal of Social Sciences), Vol: 36 Issue: 2, 203-213, 2012.

[34] Birsel Aktoy. İlköğretim Yöneticilerinin Etik Liderlik Davranışlarının Öğretmen Görüşlerine Göre Değerlendirilmesi (Şanlıurfa İli Örneği) [The Views Of Teachers From Primary School's About Their Managers Ethic Leadership Behaviours (Şanlıurfa City Sample)] Yayınlanmamış Yüksek Lisans Tezi (Unpublished Master Thesis), Harran University, The Institute of Social Sciences, Şanliurfa, 2010.

[35] İbrahim Baştuğ. İlköğretim Okulu Yöneticilerinin Etik Liderlik Davranıșlarına İlișkin Öğretmen Görüșleri (Konya İli Örneği) [Teacher's perspectives about the primary school leaders on ethical leadersip behaviours (Sample of Konya)] Yayınlanmamış Yüksek Lisans Tezi (Unpublished Master Thesis), Konya University, The Institute of Social Sciences, Konya, 2009.

[36] Ahu Taneri. İlköğretim Okullarında Etik Liderlik İle Örgüt Sağlığı Arasındaki İlişki (Aksaray İli Örneği) [The Relationship between Ethical Leadership and Organizational Health in Primary Schools (A Study in Aksaray)], Yayınlanmamış Yüksek Lisans Tezi (Unpublished Master
Thesis), Gazi University, The Institute of Social Sciences, Ankara, 2011.

[37] Muhammed Turhan. Genel Ve Mesleki Lise Yöneticilerinin Etik Liderlik Davranışlarının Okullardaki Sosyal Adalet Üzerindeki Etkisi. (The Effect of Ethical Leadership Behaviors of High School and Vocational High School Principals on Social Justice in Schools), Yayımlanmamış doktora tezi. (Unpublished doctorate thesis) Frrat University, The Institute of Social Sciences, Elazı $\breve{g}, 2007$.

[38] Sedat Çelik, Bekir Bora Dedeoğlu and Ali İnanır. Relationship between Ethical Leadership, Organizational Commitment and Job Satisfaction at Hotel Organizations. Ege Academic Review. Vol: 15 Issue:1 53-63, 2015.

[39] Alptekin Sökmen and Emre Burak Ekmekçioğlu. Yönetici Etik Davranışlarının Sınır Birim Çalışanlarının Motivasyon ve İş Tatmini Üzerindeki Etkisi: Adana'da Bir Araştırma (The Effect of Managers' Ethical Behavior on Boundary Spanning Role Employees' Motivation and Job Satisfaction: A Research in Adana) İşletme Araştırmaları Dergisi (Journal of Business Research-Turk) Vol: 5, Issue: 4, 87-104, 2013.

[40] Canan Madenoğlu Şengül Uysal, Yılmaz Sarıer and Köksal Banoğlu. Okul Müdürlerinin Etik Liderlik Davranışları ile Öğretmenlerin İş Doyumlarının Örgütsel Bağlılıkla İlişkisi (Relationships of School Principals' Ethical Leadership and Teachers' Job Satisfaction on Teachers' Organizational Commitment) (Kuram ve Uygulamada Eğitim Yönetimi) Educational Administration: Theory and Practice, Vol: 20, Issue 1, 47-69, 2014.

[41] Münevver Çetin and Kenan Özcan. Okul Yöneticilerinin Etik Davranışlarının Öğretmenlerin İș Doyumuna Etkisi (Influence of School Administrators' Ethics Behaviours On Teachers' Job Satisfaction) Marmara. University. Atatürk Faculty of Education. Journal of Educational Sciences. Volume: 20 Issue: 20, 21-38, 2004

[42] Mikail Yalçın and Engin Karadağ. Hizmetkâr Liderlik Ve Okul Kültürü: Bir Yapısal Eşitlik Modellemesi (Servant Leadership and School Culture: A Structural Equation Modeling) Inonu University Journal of the Faculty of Education Vol: 14, Issue 2, 101-120, 2013.

[43] Refik Balay, Ahmet Kaya and Reyhan Geçdoğan Yılmaz. Eğitim Yöneticilerinin Hizmetkâr Liderlik Yeterlikleri ile Farklılıkları Yönetme Becerileri Arasındaki İlişki (The Relationship between Servant Leadership Competencies and Diversity Management Skills among Education Managers). Eğitim Bilimleri Araştırması Dergisi- Uluslararası E-Dergi. (Journal of Educational Sciences Research-International E-Journal) Vol: 4 (Special Edition) Number: 1, 229-249, 2014. Online available from DOI: 10.12973/jesr.2014.4os14a

[44] Hakkı Kahveci and Ahmet Aypay. Hizmetkâr Liderlik Ve Okul Kültürü Arasındaki İlişkinin İlköğretim Okullarında İncelenmesi (An Investigation of Relationship between The Servant Leadership And School Culture in Primary Schools) (Eğitimde Politika Analizi Dergisi) Journal Of Educational Policy Analysis. Vol: 2, Issue 1, 44-60, 2013,

[45] Lora L. Reed, Deborah Vidaver-Cohen and Scott R. Colwell. A New Scale to Measure Executive Servant Leadership: Development, Analysis and Implications for Research. Journal of Business Ethics 101:415-434 _ Springer, 2011. DOI 10.1007/s10551-010-0729-1

[46] Ümit Ercan and Ünsal Sığrı. Kültürel Değerlerin Liderlik 
Özelliklerine Etkisi: Türk ve Amerikalı Yöneticiler Üzerine Bir Araştırma The Effect of Cultural Values on Leadership Behavior: (A research on Turkish and American Managers) TODAİE Amme İdaresi Dergisi, (Journal of Public Administration for Turkey and Middle East) Vol: 48 Issue. 3, 95-126, 2015.
[47] Cem Harun Meydan and Mustafa Polat. Liderin Güç Kaynakları Üzerine Kültürel Bağlamda Bir Araştırma (A Study in Cultural Context on Leader Power Bases). Ankara University, The Journal of the Faculty of Political Sciences (Siyasi Bilimler Fakültesi Dergisi) Vol: 64 Issue: 4, 123-140, 2010. DOI: 10.1501/Sbfder_0000002187 